\title{
Umění a religiozita v esteticko-filozofickém systému Dmitrije Sergejeviče Merežkovského
}

\begin{abstract}
Vorel Jan, Umění a religiozita v esteticko-filozofickém systému Dmitrije Sergejeviče Merežkovského (Art and Religiosity in the Aesthetic-Philosophical System of Dmitry Sergeyevich Merezhkovsky). „Poznańskie Studia Slawistyczne” 8. Poznań 2015. Publishing House of the Poznan Society for the Advancement of the Arts and Sciences, pp. 377-390. ISSN 2084-3011.
\end{abstract}

The study is aimed on traces of religiosity in aesthetic-philosophical system of a Russian symbolistic poet, prosaic writer and thinker D.S. Merezhkovsky. The study analyses selected Merezhkovsky's works with focus on aesthetics, his essays, historiosophic prose and philosophicreligious treatises. For Russian spiritual and art culture, importance of Merezhovsky is obvious, especially in connection with his effort to overcome crisis processes in religious, philosophical and art sphere, realized by means of synthesis and transcendence in modern culture.

KeYwords: Russian symbolism; theurgy; aesthetic-philosophical approaches; Hegelian concept of art; art and religion; synthesis in modern culture; work of art of D.S. Merezhkovsky; historiosophic prose

Na pojem krásy $\mathrm{v}$ uměleckém díle je $\mathrm{v}$ historii estetiky pohlíženo prizmatem dvou protikladných př́stupů, tzv. kantovské a hegelovské estetiky. První ji vymezuje jako „účelnost bez účelu”, „nezainteresované zalíbení”, tj. jako absolutní kategorii, která nemůže vyhovovat praktickému či etickému účelu. Tento př́stup podtrhuje myšlenku autonomního estetizmu a stal se uměleckým krédem evropské literární dekadence. Druhý směřuje k poznání vyšší jednoty, díky níž umění prostřednictvím syntézy dospívá k identitě vnějškovosti a niternosti, obsahu a formy, subjektu a objektu. Tím je dosaženo poznání podstaty krásy jako zjevování absolutní ideje v umění. Touto cestou se pak v evropských literaturách nakonec ubíral i literární symbolizmus ve své vrcholné, tzv. teurgické fázi. 
Počátek 20. století přinesl změny v estetice ruského literárního symbolizmu, který se snažil překonat estetický subjektivizmus své rané dekadentně-symbolistické etapy. $Z$ esteticko-filozofického hlediska došlo k posunu od subjektivně-individualistického chápání světa k objektivisticko-idealistickým koncepcím. V umění se zrodily koncepce syntézy a teurgie, jejichž společným rysem bylo chápání slova-symbolu obdařeného ,vyšší tvořivou silou", které ve všednodenně užívaných pojmech a slovech objevuje jejich skrytý smysl a energii a činí z nich prostředek komunikace mezi profánním a sakrálním.

Teurgie („celostní tvorba”) byla chápána jako substanciální jednota tvorby ovlivněná mystikou a náboženstvím. Její podstatou je komunikace mezi materiálním světem a světem idejí prostřednictvím ,zniterněné tvưrčí činnosti” založené na organické jednotě mezi ideální a materiální stránkou tvorby. Tím se rodí přesvědčení, že umění musí vstoupit do svobodného spojení s náboženstvím a začalo se hovořit o religiózním smyslu umění a nalezení tvořivé energie v životě člověka a kultury. Úkolem teurgie bylo vytvořit organickou metakulturu jako vrcholnou fázi ve vývoji lidské civilizace a překonat její současnou tragickou etapu. Podstatou teurgického umění se stal požadavek, aby krásno pozitivně působilo na realitu a aby bylo schopno realitu kvalitativně prohloubit. Proto je k realizaci krásna potřeba vzájemného prolínání dvou tvưrčích elementů: materializace duchovní podstaty a úplného zduchovnění materiálního světa.

V tomto smyslu se stoupenci teurgického umění staví proti antitradicionalizmu a estetickému separatizmu dekadentně-symbolistické generace. Krásno je chápáno jako životní plnost utvářející realitu a umění se stalo cestou realizace celosvětové jednoty a ideje organického života, kdy duchovně sjednocené lidstvo směřuje do jediného duchovního centra a komplexního bytí (viz symboly spojení civilizací Západu a Východu, symboly zrání a růstu, stavitelství chrámu v tvorbě představitelů této umělecké generace).

Jedním z dokladů, jak se esteticko-filozofické postoje stoupenců ruského symbolizmu ve smyslu hegelovské estetiky postupně dostávají do svobodného vztahu s religiozitou je i tvorba básníka, prozaika, filozofa a esejisty Dmitrije Sergejeviče Merežkovského, jehož tvưrčí cesta se počíná v 80. letech 19. století zálibou v pozitivizmu a teprve později vede k subjektivnímu idealizmu, religiozitě a symbolizmu. V tvůrčí osobnosti 
Merežkovského se poprvé v kontextu ruského symbolizmu dostává do rovnováhy a vzájemné komunikace umělec a religiózní filozof. Jako básník a zastánce idealistické estetiky dospěl k názoru, že to, co není v uměleckém díle přímo vyřčceno, prosvítá skrze krásu a energii symbolu a působí na vnímatele silněji, než to, co je řečeno slovy. Poznatelnému světu hmotné reality tak postavil svět symbolů jako obrazů ducha.

Do literatury vstoupil Merežkovskij v roce 1888 jako autor poémy Протопоп Аввакум a pak především básnickou prvotinou Стихотворения. Jako literární kritik na sebe upozornil statí věnovanou Antonu Pavloviči Čechovovi Старый вопрос по поводу нового таланта, která byla otištěna v časopise „Северный вестник” a v níž vystoupil jako zastánce přítomnosti ,iracionální Pravdy” v umění. V roce 1892 vychází Merežkovského druhá básnická sbírka Символьл. Песни и поэмы naplněná touhou po novém ideálním umění a celou řadu básní v ní tvoří náboženské reflexe akcentující religiózní chápání světa a vize mystického tajemství vnitřně sjednoceného bytí.

Významnou výzvou k idealizmu je i Merežkovského přednáška $O n p u$ чинах упадка и о новых течениях современной русской литературы (1893). Zde konstatuje, že ruská literatura se nachází na prahu nejhlubší krize, do níž ji přivedla realisticko-naturalistická představa umění jako občanské služby. V dobovém ruském kulturním klimatu vidí Merežkovskij dva proti sobě stojící prrístupy: vědecko-materialistický a religiózněidealistický, který předpokládá existenci vyšší ideální kultury, v níž jsou organicky spojeny všechny aspekty lidského bytí:

Наше время должно определить двумя противоположными чертами - это время самого крайнего материализма и вместе с тем самых страстных идеальных порывов духа. Мы присутствуем при великой, многозначительной борьбе двух взглядов на жизнь, двух диаметрально противоположных миросозерцаний. Последние требования религиозного чувства сталкиваются с последними выводами опытных знаний. Умственная борьба, наполняющая XIX век, не могла не отразиться на современной литературе. Преобладающий вкус толпы - до сих пор реалистический. Художественный материализм соответствует научному и нравственному материализму. Пошлая сторона отрицания, отсутствие высшей идеальной культуры (Мережковский 1914b: 536).

Literární kritiku podle Merežkovského nejvíce zajímá otázka: „umění pro život, či život pro umění'? Ta se ovšem stává pro skutečného umělce 
otázkou naprosto zbytečnou, nebot' kdo opravdu miluje krásu, ví, že umění není náhodný vnější přídatek života, ale samotný jeho dech, nebo přesněji „srdce života”, bez něhož se lidská existence stává horší smrti. Umění bez života a život bez umění tedy nemohou existovat a jejich izolace je naprosto nemožná:

мы чувствуем близость тайны, близость океана. Никаких преград! Мы свободны и одиноки! (...) С этим ужасом не может сравниваться никакой порабощенный мистицизм прошлых веков. Никогда еще люди так не чувствовали сердцем необходимости верить и так не понимали разумом невозможности верить. В этом болезненном неразрешимом диссонансе, этом трагическом противоречии так же, как в небывалой умственной свободе, в смелости отрицания, заключается наиболее характерная черта мистической потребности XIX века (Мережковский 1914b: 536).

Nový umělecký směr si tedy musí za svůj cíl vytknout odklon od materializmu a pozitivizmu a směřovat $\mathrm{k}$ novému idealizmu vyvěrajícímu z bezprostřední intuice nejhlubšího tajemství umělecké tvorby a ze samotné hlubiny současného evropského a také ruského ducha: „Непростительная ошибка - думать, что художественный идеализм - какое-то вчерашнее изобретение парижской моды. Это возвращение к древнему, вечному, никогда не умиравшему" (Мережковский 1914b: 537). Jeho konstituování spočívá v prolínání následujících prvků v umělecké tvorbě: zvýšená umělecká vnímavost, mystický obsah spojený s nábožensko-filozofickou podstatou tvorby, symbolizace, symbolický styl a symbol jako „věčný příznak skutečného umění" spojený odpradávna s mýty a obřady, který definuje jako znak, obraz, vystupující z hlubin skutečnosti a směřující zpětně k jejímu hlubšímu poznání. Zatímco slovo podle Merežkovského „ohraničuje myšlenku”, symboly naopak vyjadřují její „,neohraničenost” a ukazují cestu $\mathrm{k}$ hlubším duchovním obsahům:

Таковы три главных элемента нового искусства: мистическое содержание, символы и расширение художественной впечатлительности... (...) Символы должны естественно и невольно выливаться из глубины действительности. Если же автор искусственно их придумывает, чтобы выразить какую-нибудь идею, они превращаются в мертвые аллегории, которые ничего кроме отвращения, как все мертвое, не могут возбудить. (...) Мысль изреченная есть ложь. В поэзии то, что не сказано и мерцает сквозь красоту символа, действует сильнее на сердце, чем то, что выражено словами. Символизм делает самый стиль, самое художественное 
вещество поэзии одухотворенным, прозрачным, насквозь просвечивающим, как тонкие стенки алебастровой амфоры, в которой зажжено пламя (Мережковский 1914b: 538).

První prŕíznaky idealizmu v ruské literatuře 19. století podle Merežkovského pomalu vyplouvají na povrch z ,podvědomí” kritického realizmu. Merežkovskij ukazuje, že spisovatelé předcházejících literárních generací (Gončarov, Turgeněv, Dostojevskij, Tolstoj), nehledě na „,vnější realizmus” svých románů, prostřednictvím filozofických zobecnění a symbolů, impresionistických nálad, fantastických obrazů, hlubinných psychologických sond a hledáním životní pravdy vyjádřili silnou mystickou potřebu renesance idealistického umění, která se znásobuje v tvưrčím úsilí nastupující umělecké generace. Zmínění autoři činí umění otevřeným problematice daleko širší a transponují ho do vyšších sfér, kdy se ocitáme tváríi v tvář „,nekonečnosti, Bohu, smrti", tedy všemu, co pozitivisté chtěli z jejich tvorby násilně vytěsnit.

Cestu nového uměleckého pokolení vidí Merežkovskij jako cestu z období, ,živelného” k období „kritickému, vědomému a kulturnímu”. Mezi nimi ale zeje hluboká propast, na jejímž jednom okraji je boj mladých spisovatelů a kritiků s literární minulostí a mezi jehož symptomy patř́ projevy dekadence. Na okraji druhém je živoucí umělecká tvorba - budoucí mladosymbolizmus spojený se solovjovovskou vizí celostního nazírání na umění a představou umělecké tvorby jako teurgie.

Umělecké dílo a kritická tvorba je podle Merežkovského zrcadlením duše člověka, nehovoří zde „publicista” vytvářející objektivní vědeckou analýzu, ale především ,člověk o člověku” a „umělec o umělci”. Nejhlubší inspirací moderního umění a kritiky je „živoucí láska” a upřímný respekt k mravní svobodě tvůrce, filozofující přístup a směřování $\mathrm{k}$ idealizmu a religiozitě. Touto cestou podle Merežkovského kráčí i filozof a básník Vladimír Sergejevič Solovjov se svou ideou „Všejednoty” a představou „bohočlověka” jako realizace spojení hlubokého religiózního cítění s touhou po pozemské spravedlnosti. Svoje úvahy o smyslu moderního umění nakonec uzavírá představou, že bez víry v božskou podstatu světa nemohou existovat ideje krásy a svobody.

Klíčem k pochopení Merežkovského esteticko-filozofického systému je i jeho historiosofická próza. Jejím sjednocujícím motivem je filozoficko-mystická cesta k celostnosti a psychologické plnosti člověka a civilizace, př́konávající protiklad nebeského a pozemského a vedoucí 
k harmonické syntéze. Z tohoto hlediska tvoří naprostá většina jeho děl ucelený systém, v němž se zrcadlí koncepce mysticko-religiózní geneze světa a lidstva.

Osudy hrdinů Merežkovského románů (viz trilogie Христос и Антихрист [Смерть богов. Юлиан Отступник, 1896; Воскресшие боги. Леонардо да Винчи, 1901; Антихрист. Петр и Алексей, 1905]) jsou bezprostřední výpovědí o hledání smyslu vývoje světa, pravdy, duchovní a hodnotové stability na pozadí střetu dvou epoch. V trilogii Kristus a Antikrist se tyto dva protiklady stávají nejen alegoriemi křest'anství a pohanství, ale především symboly, jejichž význam lze nahlížet i prizmatem Dostojevského filozofie jako přítomnost polárních principů člověkoboŽského a boholidského uvnitř lidské duše.

V myšlenkovém světě Merežkovského se do těsného vztahu dostaly i dva $\mathrm{v}$ tehdejším ruském kulturním prostředí dominantní filozofické a estetické př́istupy reprezentované Nietzschem a Solovjovem. První hlásá překonání současného člověka a příchod nekonečně svobodného „nadčlověka" - antikřest’ana, který miluje pozemský život, žije podle zákonů Síly a Krásy a pro něhož je svět jen estetickým fenoménem. Druhý z nich chápe světový vývoj jako postupnou realizaci božské ideje, formuluje představu „Všejednoty” jako syntézu Pravdy, Dobra a Krásy a vidí genezi světa jako cestu $\mathrm{k}$ „,bohočlověku”, představujícímu konečné spojení matérie a ducha, země a nebe.

Sám autor během práce nad trilogií nahlížel na její smysl takto:

Когда я начинал трилогию (...) мне казалось, что существуют две правды: христианство - правда о небе и язычество - правда о земле и в будущем соединении этих двух правд - полнота религиозной истины. Но кончая, я уже знал, что соединение Христа с Антихристом - кощунственная ложь, что обе правды (...) уже соединены во Христе Иисусе (...) что в Нем Едином - не только совершенная, но и бесконечно совершаемая, бесконечно растущая истина, и не будет иной (Мережковский 1914a: VI).

V první části trilogie jsme svědky tragického úpadku antické kultury. Císař Julián (331-363), estét a hrdý aristokrat nietzscheniánského ražení se snaží zastavit a změnit chod historických událostí, fanaticky bojuje s demokratickým duchem rozmáhajícího se křest’anství a „plebejskou morálkou slabých". Vznešený a hrdý antický svět nakonec zaniká a ustupuje nové kulturní epoše, avšak v samotném závěru románu jedna z postav 
- Arsinoé, dříve vášnivá pohanka, poté křest’anka, která ani v jedné z obou fillozofií nenachází úplnou pravdu o světě, se nakonec stává ztělesněním nové pravdy o spojení obou protikladů a hlásá vizi znovuzrození antické kultury. V románu tedy nedochází $\mathrm{k}$ harmonické syntéze dvou proti sobě stojících principů, ta je v podstatě nahrazena její nepravou podobou, nebot' chaos, který plodí historické události, zrodí lživou podobu syntézy a oba principy ztrácejí svůj hlubinný smysl: vznešené pravdy jsou zprofanizovány, pohanství se stává vzorem morálky a křest’anství, vtažené do chodu pozemských věcí „Antikristova světa”, mění svoji podstatu, stává se vírou fanatického davu a součástí státního systému, postaveného na despocii, násilí a zradě.

Naplněním proroctví je část druhá, kdy v souladu s některými myšlenkami Nietzscheho filozofického systému dochází k oživení antického ducha, znovunastolení kultu aristokratizmu a probuzení lidského „Já”. Snahy o obrodu kultury ale nakonec končí na hranicích svaté inkvizice. I zde je z myšlenkového a kompozičního hlediska vše podřízeno střetu dvou extrémních protikladů. Svět „Antikrista”, krásy a zla je světem představitelů církve a státu, světem dobových filozofů a světem geniálních umělců tvořících svá díla „mimo dobro a zlo”. Vše, co překonává morálku, patří bezvýhradně světu „Krásy”. Svět „Krista”, je v románu reprezentován temným, asketickým a fanatickým chápáním Kristova poselství, jehož nositelem je světec a inkvizitor Savonarola.

Jedinou realizací ducha syntézy se v románu stává postava Leonarda da Vinci, silné tvořivé osobnosti, v níž se ukrývá síla krásy a poznání a která stojí nad náboženskými a politickými zájmy a nad všemi city a vášněmi. Idea syntézy těla i ducha, pohanského a křest’anského je nakonec prrítomna ve vrcholných dílech Leonarda, kde spolu v nekonečné harmonii koexistují symboly pozemského a nebeského. Prostřednictvím těchto uměleckých obrazů Merežkovskij zastává názor, že svět umění stojí vždy nad historickou realitou, nebot' se v něm ukrývají prorocké vize o skutečném směřování člověka.

Ve třetí části trilogie jsou proti sobě postaveni Petr I. a jeho syn Alexej jako symboly extrémních principů formujících vývoj historie a kultury, ale i život jednotlivce. První symbolizuje individuální vůli, racionalistický Západ a druhý „,duch národa a světa”, „,pravdu Krista”, které Merežkovskij ztotožňuje s církví a východní spiritualitou. Zápas „otce” a „syna” 
je v symbolické rovině chápán jako zápas dvou myšlenkových principů. První nakonec vítězí, nicméně prostřednictvím Alexejovy předsmrtné vize promítá Merežkovskij do románu ideu syntézy obou principů v království „Třetího zákona” (viz níže).

V celé své tvorbě literární, kritické a publicistické se Merežkovskij dotýká nábožensko-fillozofických otázek a vypracovává originální náboženské a filozofické teorie, které jdou vždy ruku v ruce s jeho uměleckými a tvưrčími záměry. I nábožensko-filozofická shromáždění, kde figuroval jako jeden z hlavních organizátorů, měla vytvořit svobodnou tribunu pro posuzování otázek církve a kultury, novokřest’anství a otázek společenských. Protokoly shromáždění byly vydávány časopisem „Новый путь” a obsahovaly dva výrazné tematické okruhy: filozoficko-náboženský a estetický.

Cestu z krizového stavu kultury Merežkovskij nakonec nachází v myšlence „obnoveného křest’anství”. Ve svých nábožensko-filozofických esejích projevuje zájem o podobné otázky jako ve své historiosofické trilogii. Spolu s básnířkou Zinaidou Nikolajevnou Gippiusovou, vypracoval koncepci „nového religiózního vědomí”, považovanou za „kulturně-náboženskou renesanci", která stála $\mathrm{v}$ ostrém protikladu nejen $\mathrm{k}$ pozitivistické filozofii, ale i k evropské církevní tradici. Jádrem této koncepce je myšlenka, že v dějinách lidstva a kultury dochází k několikerému zjevení „boží moci”. Ve Starém zákoně (zákoně Boha-otce) se zjevila jako pravda, v Novém zákoně (zákoně Boha-syna) jako láska a ve třetím - přicházejícím (zákoně Svatého Ducha) - se láska zjeví jako svoboda a lidstvo pozná nové jméno „Přicházejícího”, jímž je „Osvoboditel”.

„Třetí zákon” se měl stát „náboženstvím Svatého Ducha”, syntézou pohanství jako „pravdy o zemi” a křest’anství jako „pravdy o nebi”. Duchovní historii lidstva Merežkovskij chápal jako věčné střetávání dvou nedokonalých principů, které sám nazývá ,propastí těla”, ztělesněnou v pohanství a ,propastí ducha”, jíž odpovídá křest’anská askeze. Překonání těchto dvou polarit bytí viděl v jejich syntéze skrze „duchovní revoluci”, kterou měla uskutečnit nová „Církev Třetího zákona”. V tomto smyslu Merežkovskij považoval také sám sebe za „proroka nového religiózního vědomí" a jeho koncepce prrímo respektovala hlavní zákony dialektiky, tj. konflikt teze a antiteze, z něhož se rodí idea syntézy vytvářející nový organický systém. 
Hlavním cílem Merežkovského uvažování se stala představa obnovy tradičního křest’anství. Své nábožensko-filozofické úvahy soustředí do tří zdánlivě naprosto odlišných, nakonec ovšem organicky propojených problémových sfér: problém pohlaví, svatého těla a sociální spravedlnosti, jíž je dosaženo cestou realizace křest'anství v životě společnosti. První sféry se dotýká nejvíce ve své knize Таŭнa mpex (1925). Zde vykládá tajemství Jednoho - Boha Otce jako tajemství Božského Já. Tajemstvím dvou je vztah Já a ne-Já, přičemž, ne-Já mne vylučuje, ničí mne, nebo ničím já je. Výjimku zde představuje pohlaví, které chápe jako „vstupování jedné bytosti do druhé", kdy se rodí bytost nová. V náboženské sféře takto nahlíží na zrození Syna v Trojici. Tajemstvím Druhého je tedy Pohlaví a tajemstvím Tř́i je tajemství Svatého Ducha - sjednocení Tří osob v Duchu, dosažená vyšší jednota představující archetyp Božího Království.

Základem osobnosti je tedy podle Merežkovského cítit sám sebe ve svém těle, základem pohlaví cítit sám sebe v těle druhém a základem společnosti cítit sám sebe ve všech ostatních tělech. Merežkovského „dva budou jedno tělo" se tedy nevztahuje pouze na manželský svazek, ale především na nejvyšší jednotu (Božské společenství), která souvisí se třetí osobou Svaté Trojice - Svatým Duchem. Na základě aramejštiny, kde slovo Ruha označuje Ducha a je ženského rodu, a jednoho z tradovaných agrafư, kde Ježíš ř́ká: „Má matka je Duch Svatý”, chápe nakonec Merežkovskij složení Svaté Trojice jako - Otec, Syn a Matka-Duch.

Ideál Boha jako jednoty mužského a ženského principu tak nakonec Merežkovskij přenesl na své chápání člověka. Dokonalou lidskou bytostí je Merežkovskému představa androgyna, který překonává rozdělení člověka na dvě poloviny opačného pohlaví, což vedlo v dějinách lidstva k ,úpadku osobnosti”. Ruský filozof Nikolaj Onufrijevič Losskij (18701965) ve svých Dějinách ruské filozofie (Historie de la philosophie russe des origines à 1950, Paříž 1954) komentuje Merežkovského nábožensko-filozofické postuláty následovně:

Ideálem osoby je podle Merežkovského, stejně jako podle Solovjova a Berd'ajeva, androgyn. To jest spojení muže a ženy do jedné celistvé osoby. Takový názor však mohou akceptovat jen filozofové, kteří popírají substancialitu já. Takoví, kteří především neuznávají nadčasovost a nadprostorovost individuálního já. Já je díky své substancialitě individualita $\mathrm{v}$ doslovném smyslu slova. Je to bytost absolutně nedělitelná a nerozložitelná na dvě poloviny. Muž i žena jsou osoby nedokonalé jen v tom smyslu, že muž má 
duchovní vlastnosti, které obvykle ženy nemají, a naopak ženy mají duchovní vlastnosti, které obvykle nemají muži. Ideálem osoby je spojení mužských a ženských duchovních hodnotných vlastností. Lze jej zrealizovat zdárným rozvojem našeho já, nikoliv tedy nemožným a nesmyslným spojením dvou já v jedno já (Losskij 2004: 531-532).

Toto pojetí je blízké prapůvodním mýtům o božské a lidské androgynii. Mircea Eliade v knize Pojednání o dějinách náboženství uvádí, že většina mýtů obsahuje dvě významná sdělení. Jde jednak o polaritu dvou božských bytostí, které vychází z téhož principu a které se nakonec musí sjednotit, jednak o symboliku spojení protikladů (coincidentia oppositorum) patřící k bytostné povaze božstva (božstvo laskavé i hrozivé, tvořící i ničící). Z toho vyplývá i samotná podstata božstva, jehož primární úlohou je konečné sjednocení všech protikladů.

Mýtus o božské androgynii vychází z představy, že v božstvu jsou sjednoceny všechny atributy a že $\mathrm{v}$ něm také budou koexistovat dvě pohlaví: „Božská androgynie není ničím jiným než prastarým výrazem božské dvojjedinosti; ještě než mytické a náboženské myšlení vyjádřilo představu božské dvojjedinosti jazykem metafyziky (esse - non esse) nebo teologie (zjevený - nezjevený), vyjádřilo ji nejprve jazykem biologie (bisexualita)" (Eliade 2004: 409). Na konci starověku se v novoplatónském a gnostickém myšlení objevuje mýtus o božstvu, které přijalo jméno „otec a matka” a z něhož se bez sebemenšího zásahu zvenčí rodí světy a bytosti.

Mýtus božské androgynie se ve vývoji náboženského myšlení stal praobrazem pro celou řadu mýtů a rituálů, které souvisí s androgynií lidskou. Celá řada z nich považuje „,prvotního člověka” za androgyna (chápání Adama v některých rabínských komentáŕích, Platónova či gnostická antropologie). Tento mýtus tedy nakonec posloužil jako pravzor pro celou řadu obřadů, jejichž podstatou je pravidelná aktualizace počátečního stavu považovaného za dokonalý způsob existence lidstva: „Člověk zkrátka pravidelně pocit'uje potřebu vrátit se do stavu dokonalého lidství, v němž obě pohlaví existovala současně tak, jako existují - vedle všech ostatních vlastností a atributů - v božstvu" (Eliade 2004: 409, 412).

Spojení obou pohlaví v tomto rituálu na okamžik člověku usnadňovalo úplné pochopení kosmu. S tím souvisí i lidská potřeba pravidelně narušovat rozlišený a předem daný stav a vrátit se k ,prvotní celistvosti” - „Všemu-Jednomu”. Stejně jako Merežkovskij i Eliade poukazuje na fakt, 
že v některých náboženstvích a filozofiích (viz např. německá romantická ideologie) lze androgynizace dosáhnout sňatkem či pohlavním aktem: „V podstatě se dá dokonce mluvit o androgynizaci člověka láskou, protože v lásce každé pohlaví nabývá, získává kvality pohlaví opačného (zamilovaný muž se stává laskavým, poddajným, oddaným atd.)" (Eliade 2004: 413).

Představa Merežkovského o ideálu člověka a civilizace tedy není netělesnou svatostí, ale naopak posvěcenou tělesností, kterou považuje za „Královstí Boží”, kde se uskutečňuje mystická jednota těla a ducha. Celá jeho religiózní filozofie je tedy založena na představě křest’anství jako „náboženství lásky a svobody”, kde musí naprosto vymizet mnišství a asketizmus a na jejich místo nastoupit umění jako integrální součást náboženství, jako tvorba mající religiózní dimenze ${ }^{1}$. Stejně jako bylo pro Merežkovského konečným cílem vývoje lidské civilizace sjednocení těla a ducha, neméně vážnou podobou syntézy se stala i syntéza náboženství a kultury. To samozřejmě souvisí i s jeho představami o ideálním uspořádání světa. Merežkovskij předpokládal, že křest’anství „Třetího zákona” bude lidstvo sjednocujícího, ekumenického charakteru, tj. syntézou katolictví, protestantizmu a pravoslaví.

Základním rysem Merežkovské esteticko-filozofického uvažování je tedy, jak mimo jiné ve své stati Новое христианство uvádí významný ruský filozof Nikolaj Alexandrovič Berd'ajev, princip „binárních opozicí” (křest'anství - pohanství, duch - hmota, ženský - mužský princip), tj. teze (,dogmatického materializmu”) a antiteze (,dogmatického idealizmu"), jejichž spojením je vytvořena nová religiózně-kulturní syntéza (,mystický materializmus”). Takovým způsobem dospívá Merežkožkovskij prostřednictvím ducha syntézy $\mathrm{k}$ překonání dvou myšlenkových

\footnotetext{
${ }^{1}$ Problematiky těla a ducha se Merežkovskij dotýká ve svém proslulém traktátu Толстой и Достоевский (1905) věnovaném tvůrčímu a duchovnímu hledání těchto dvou autorů. Na tvorbu Lva Nikolajeviče Tolstého pohlíží jako na „vizionářství těla”. Na tvorbu Fjodora Michajloviče Dostojevského naopak jako na „vizionářství ducha”. Jak Tolstoj, tak i Dostojevskij podle něho uhadují tajemství „nového zjevení”, přičemž v tušení jeho blízkého příchodu Tolstoj postihuje samotnou podstatu ,tajemství těla” a Dostojevskij zase naopak ,tajemství ducha”. Merežkovskij nakonec straní tvưrčí a nábožensko-filozofické koncepci Dostojevského, který na své cestě k poznání tajemství ducha dochází až k samotné hranici, za níž člověka čeká pochopení nejvyšších nábožensko-mystických tajemství bytí, což považuje za poslední stádium v poznání podstaty světa.
} 
protikladů formujících lidskou civilizaci a k pochopení „třetí pravdy”, která iniciuje „,nové religiózní vědomí” a napomáhá duchovnímu přerodu světa a kultury.

Svou erudicí a tvůrčí originalitou patřil Merežkovskij k nejvýraznějším osobnostem ruského umění a fillozofie přelomu století. Jako jeden z prvních zformuloval základní tvůrčí a myšlenkové principy ruského symbolizmu tím, že ho vymezil proti dekadenci. Do dějin literatury vstoupil jako zakladatel žánru historiosofického románu, za jehož přímé pokračovatele jsou považováni klasikové moderního evropského románu (Bělyj, Remizov, Mann, Joyce aj.). Spolu s Vladimírem Sergejevičem Solovjovem a Vasilijem Vasilijevičem Rozanovem se stal průkopníkem religiózně-filozofického př́stupu k umění, který dovršili ruští mladosymbolisté. Jeho umělecká a esejistická tvorba vešla v širokou známost i za hranicemi Ruska a vysokého ocenění se jí dostalo třeba ze strany Sigmunda Freuda, německých expresionistů a Thomase Manna. Význam Merežkovského pro ruskou duchovní a uměleckou kulturu je však neopominutelný především v souvislosti s jeho snahou o překonání krizových procesů v religiózní, filozofické a umělecké sféře prostřednictvím ducha syntézy a jeho protetickým viděním cesty $\mathrm{k}$ transcendenci $\mathrm{v}$ moderní kultuře.

\section{Literatura}

Broch H., 2009, Román-mýtus-kýč: eseje, přel. N. Macurová, Praha.

Eliade M., 2004, Pojednáni o dějinách náboženství, přel. J. Vacek, Praha.

Losskij N.O., 2004, Dějiny ruské filozofie, přel. A. Černohous, Velehrad-Roma.

Merežkovskij D.S., 1929, Tolstoj a Dostojevskij: život, tvorba, náboženství, přel.

J. Bečka, Praha.

Naldoniová L., 2010, Erós a jeho metamorfózy, Ostrava.

Naldoniová L., 2012, Ruská sofiologie a věčné ženství, Ostrava.

Řezníčková L., 2004, Moderna a historismus. Historické reprezentace v proměnách literatury na prelomu devatenáctého a dvacátého století, Praha.

Zima P.V., 1995, Literární estetika, přel. J. Schneider, Olomouc.

Бердяев Н.А., 1989, Новое христианство, in: Н.А. Бердяев, Собрание сочинений, sv. 3: Типы религиозной мысли в России, Париж.

Викторович Д.О., 1999, Д. Мережковский: Преодоление декаданса (раздумья над романом о Леонардо да Винчи), Москва.

Евлампиев И.И., 2014, История русской философии, Санкт-Петербург. 
Замалеева А.Ф. (ed.), 2012, История русской философии, Санкт-Петербург.

Кулешова О.В., 2007, Притчи Дмитрия Мережковского. Единство философского и художественного, Москва.

Мережковский Д.С., 1914a, Полное собрание сочинений, sv. 1, Москва.

Мережковский Д.С., 1914b, Полное собрание сочинений, sv. 18, Москва.

Мережковский Д.С., 1999а, Мысль и слово, Москва.

Мережковский Д.С., 1999b, Тайна трех, Москва.

Михайлов О.Н., 2001, От Мережковского до Бродского. Литература Русккого зарубежья, Москва. 
